MELUZYNA

ISSN 2449-7339

2 (11) (2019) I Rocznik VI

DOI: $10.318 / m e .2019 .2-03$

PRZEKROJE | ZBLIŻENIA

\author{
Noemi Szafrańska* \\ Uniwersytet Jagielloński w Krakowie \\ ORCID ID 0000-0002-6531-6343
}

\title{
Seksualność Paskwaliny, czyli o specyfice poematu Samuela Twardowskiego raz jeszcze
}

W 1927 roku Aleksander Brückner stwierdził, że „w Nadobnej Paskwalinie po raz pierwszy nakreślono z wdziękiem obraz kobiety zalotnej, jej zaigrywań z miłością" (Brückner, 1927, s. 21). Od czasu ukazania się artykułu badacza minęło lat sporo, a przywołane zdanie wydaje się wciąż niedostatecznie rozwinięte, pomimo istnienia licznych, często wobec siebie polemicznych prac poruszających problem erotyki romansu Samuela Twardowskiego. Polemicznych najczęściej z powodu odmiennych odczytań nadbudowy narracyjnej, która pozwala na dwojakie rozumienie zwłaszcza wymowy ideowej. Najogólniej rzecz ujmując, przez pryzmat Nadobnej Paskwali$n y^{1}$, wydanej w roku 1655, postrzegany był Twardowski jako moralista lub ironista-obserwator, co podczas analizowania tematu seksualności romansowej heroiny ma znaczenie zasadnicze.

Gwoli przypomnienia fabuły: wydarzenia mają swój początek w Lizbonie, w pałacu zamieszkałym przez tytułową Paskwalinę. Akcję właściwą poprzedzają jednak trzy rozległe opisy: miasta, pałacu i urody bohaterki. To one tworzą osobliwy klimat utworu i, co jest być może nawet bardziej znaczące, wprowadzają odbiorcę w stan delikatnego rozchwiania - jak zauważa Marcin Pliszka, poemat Twardowskiego to „fascynujący świat onirycznych przedstawień, połączenie realności i fikcji” (Pliszka, 2002 s. 244), przy czym realność jest przez niego określona jako „przerysowana” i „zdeformowana”. Czytelnik już od pierwszych stron oscyluje na granicy rzeczywistości nacechowanej onirycznie i świata jawy, wyraźnie odczuwalne jest stąpanie po niepewnym gruncie warstwy narracyjnej. Baśniowa Lizbona określona zostaje przez Grzegorza Raubo jako miasto, w którym znaczące są przede wszystkim spojrzenia - rola doznań wzrokowych jest

e-mail autorki: noemiszafranska@gmail.com

Wszystkie cytaty podaję za edycją: Twardowski, 1980. 
doniosła nie tylko dla czytelnika, ale przede wszystkim dla postaci poematu. Jak można się domyślać, zwłaszcza męska część mieszkańców jest oczarowana urodą Paskwaliny. Punktem zapalnym staje się przyrównanie jej powabu do piękna Wenery - jeden z mężczyzn opiniuje, że heroina jest atrakcyjniejsza od bogini. Twierdzi tak również sama protagonistka, więc za winy swoje i swojej matki zostaje ukarana nieszczęśliwą miłością do Oliwera. W szaleństwie słucha zatem wskazówek Stelli, opiekunki, i udaje się do świątyni Minerwy po radę, która ma jej pomóc w wyjściu z cierpienia oraz odzyskaniu szacunku i podziwu mieszkańców Lizbony. Tam otrzymuje dyspozycje w związku z dalszą podróżą do świątyni Junony, która w ujęciu Minerwy jawi się jako pielgrzymka pokutna. Pomoc otrzymuje od rybaka, pasterzy, Apollina i Diany, aż udaje jej się dotrzeć na złotą łąkę - wydarzenia na niej rozegrane stanowią punkt kulminacyjny: Paskwalina mści się za spisek Wenery oraz jej syna, który sprowadził na nią nieszczęśliwą miłość, i niszczy atrybuty Kupidyna. Zostaje przez niego wprawdzie w ramach odwetu związana, ale ratuje ją Satyr i finalnie bohaterka doznaje oczyszczenia o zabarwieniu transgresyjnym - z rozerotyzowanej piękności zamienia się w pokorną fundatorkę klasztoru. Narzucający się wniosek o moralizatorskiej wymowie romansu okazuje się jednak nie tak oczywisty po przeanalizowaniu warstwy narracyjnej.

Jak zauważył już Paweł Bohuszewicz (Bohuszewicz, 2008, s. 143-155), alegoreza pozwala na znalezienie $\mathrm{w}$ wierszowanym romansie epickim argumentów przemawiających na korzyść każdej z dokonanych interpretacji. Zainspirowana głównie artykułem Agnieszki Czechowicz (Czechowicz, 2002, s. 221-234) proponuję więc prześledzenie procesu budowania, a potem ustawicznego negowania tożsamości seksualnej Paskwaliny w kontekście koncepcji mimetycznej René Girarda. Analizuję także fragmenty o zabarwieniu ironicznym. Pomocne będą także wybrane komentarze oraz badania dotyczące realiów życia codziennego kobiet w wieku XVII dzięki nim możliwe staje się uwypuklenie wrażliwego zmysłu obserwacji Samuela Twardowskiego, subtelnie kodowanego w tekście. Ujmując rzecz inaczej, spróbuję nakreślić, co poprzez konkretne zabiegi w akcie kreowania świadomości seksualnej kobiety autor mógł chcieć uzyskać lub jeszcze inaczej - jakiego wydźwięku nabiera sam tekst.

Utwór powinien wzbudzić czujność przede wszystkim pewną odmiennością w sposobie przedstawiania postaci kobiecej - narrator Nadobnej Paskwaliny wyposażony jest we wrażliwość podobną do emocjonalności narratora Dafnis drzewem bobkowym (por. Obremski, 2016, s. 287-300). Krzysztof Obremski zwraca uwagę przede wszystkim na wyraźne zasygnalizowanie, a wręcz werbalizację przeciwieństw „między tym, jaka ówcześnie panna powinna być, a tym, jaka była” (Obremski, 2016, s. 289). Paskwalina jest przede wszystkim heroiną o rysie narcystycznym, na co dowody przytacza narrator w całym Punkcie I utworu, od wersów 150-154 rozpoczynając:

\section{[...] białogłowa dziwnej}

Niesłychanie gładkości, Paskwalina, która

Nie chcąc być tym przymiotem od nikogo wtóra,

Zaraz się nie pomału tym poturbowała,

Że na jej prowincyją Wenus najachała.

(Punkt I, w. 150-154) 
Słowa chłopca, który zrównuje ze sobą boginię i Paskwalinę, rozumiane przez Czechowicz jako prowokacja, nie muszą o tym wcale upewniać bohaterki - sama wypowiada ten osąd o wiele wcześniej:

Więc się być upatrując w takiej swej ozdobie

I wiedząc to do siebie - tak barzo się w sobie

Nad wszytko rozkochała, że też pomyśliła,

Jako by w tym Wenerze samej nie spuściła

(Punkt I, w. 215-218).

Protagonistka jest nie tylko świadoma własnych wdzięków, ale z podziwianą przez narratora precyzją je wykorzystuje, celowo różnicując sposób zachowania w zależności od poziomu wstydliwości i charakteru adoratorów:

Tak ostrożnie umiała postępować sobie,

Że wszystkim twarz jednako wdzięczną i łaskawą,

A nikomu nie szczerą, nikomu nie prawą

W rzeczy pokazowała. Kogo li wstydliwym,

Abo młodym widziała, abo bojaźliwym,

Tak oczy weń wlepieła, tak mu smakowała

Krwawe usta - jakoby ich nie umykała.

Kogo zaś natarczywym abo barzo śmiałym,

Tak go wnet animuszem uniosła wspaniałym,

Że oczu pomrużywszy wstydliwych ku ziemi,

Za szrankami została swymi panieńskiemi.

(Punkt I, w. 258-268)

Szczytem samouwielbienia jest jej zachowanie w pokoju o kryształowych oknach, które tylko pozornie wydawać się może niewinne - Paskwalina obserwuje przecież tylko innych, „sama nie widziana” (Punkt I, w. 293). Jednak w momencie, kiedy podczas ubierania, czesania i ogólnych przygotowań do późniejszego „monstrowania się”, bohaterka zaczyna słuchać podokiennych rozmów na własny temat, rysuje się obraz jeszcze bardziej nieprzystający do ogólnie znanych kanonów cnoty niewieściej. Nijak ma się Paskwalina do wzoru opisanego przez Zbigniewa Kuchowicza, przyjętego „w tradycyjnej kulturze mieszczańskiej, preferującej model kobiety angelizowanej, aseksualnej” (Kuchowicz, 1992, s. 277). Jak słusznie zauważa Grzegorz Raubo, zwierciadło, w którym kobieta się przegląda, służy między innymi „społecznej autokreacji” (Raubo, 2002, s. 191). A jak kreuje swoją postać Paskwalina? Najpierw, stojąc nago przed lustrem, które odbija nie tylko samą bohaterkę, ale też kryształowe okna i wywołuje iluzję przeźroczystości, zaciera granicę między sferą prywatną a publiczną (jakże ważną w społecznym konstytuowaniu kobiety!), aby następnie, po ubraniu się, otworzyć okna i nasłuchać się przed wyjściem porównań do najpiękniejszej z bogiń. Później z kolei protagonistka wychodzi z pokoju i słucha dalej, zyskując w dodatku możliwość prowokacji i flirtu $\mathrm{z}$ adorującą ją męską publicznością. Paskwalina nie będzie więc „wstydliwą, skromną panną” (cyt. za: Obremski, 2016, s. 289), która 
poddana rodzicom i kawalerowi nie może mówić o swoich uczuciach oraz której nie przysługuje prawo wyboru partnera. Ale nie będzie też barokową heroiną przełamującą radykalnie ówczesne stereotypy kobiecości - bohaterkę można na podstawie przywołanych fragmentów określić jako głęboko samoświadomą i silną osobowość, nie zapominając jednocześnie, że ta sama osobowość budowana jest przede wszystkim w odniesieniu do pochwał adoratorów.

Właśnie ta chwiejność tożsamości Paskwaliny jest dowodem na wyjątkową wrażliwość narratora, którą rozumiałabym jednak nie za Jakubem Z. Lichańskim jako umiejętność dostrzegania „pewnych wartości, które posiadają kobiety, a których, w jakimś stopniu, brak mężczyznom” (Lichański, 1999, s. 135-159), ale jako szczególnie wyczuloną zdolność obserwowania problemów kobiet XVII wieku. Paskwalina chce być samowystarczalna i nie może, ponieważ w pracy nad tą samowystarczalnością nie potrafi wyjść poza ciągłe porównywanie się do męskiej części mieszkańców Lizbony. Bierność płci żeńskiej zostaje przełamana także dzięki wyborowi gatunku. Jak zauważa Halina Wiśniewska:

Spośród wielu utworów tylko w romansach współpartnerkami przygód miłosnych były niewiasty. Miały one możliwość wypowiedzi o sobie, podejmowania trudnych decyzji, chociaż to męski autor był narratorem i kreował drogę ich cierpień i radości (tonowanych obyczajem, np. o miłości fizycznej pisano, gdy para tworzyła związek małżeński). Natomiast w innych nieromansowych utworach białogłowa to postać w tle, czasem adresatka, do której utwór kierowano, ale która na ogół był bierna i niema (Wiśniewska, 2003, s. 266).

Nie bez znaczenia jest też fakt, że Paskwalina komunikuje się z Oliwerem listownie - protagonistka podejmuje się aktywności pisarskiej, uosabia odwagę w porzucaniu stereotypu kobiety-niemowy, kobiety niesięgającej po pióro, aby chwilę później żałować, że w ogóle pomyślała o pisaniu o swoich uczuciach: „Tu już swą nieuwagę i znaczny błąd widzi, / Że się dała w te listki. O! Jako się wstydzi” (Punkt I, w. 925-926). Narratorowi zależy na tym, żeby ukazać jej zagubienie w działaniu, jak się z tym czuje i czym się to kończy, to znaczy: oddać skomplikowany charakter rzeczywistości życia codziennego i budowania spójnej wewnętrznie osobowości „Chce, nie chce, i pragnie, i nie wie, / Co ma czynić” (Punkt I, w. 791-792). Paskwalina próbuje działać na własnych zasadach, zwłaszcza jeśli chodzi o jej upodobania erotyczne, ale nieustannie dostaje sygnały, że nie jest to właściwe zachowanie dla kobiet. Z każdym czynem przełamującym normę społeczną wikła się paradoksalnie coraz bardziej w system androcentrycznych konstruktów dotyczących zachowań stosownych dla płci pięknej. Jej sposoby spędzania wolnego czasu (przechadzki, przejażdżki, flirtowanie) wydają się w kontekście porad mężów XVII wieku zajęciami karygodnymi:

Panny mają być nie próżnujące, ale robotne; nie próżnujące, aby się mogły doma łacno osiedzieć, ponieważ powiedzieliśmy być ich tę powinność: w domu zawżdy być, przechadzek nie stroić próżnych, a nie mogą się osiedzieć, ażby się czym zabawiły przystojnym. Przystojnym, mówię, iż insze są zabawy męskie, jako uczyć, rządzić, kupczyć, żołnierką służyć, a insze białogłowskie, jako prząść, szyć, wyszywać, haftować (cyt. za Grześkowiak, 2012). 
[...] ma siedzieć jako gołębica nad wodami, nie latać, nie biegać, nie przejeżdżać się, gdyż licentio wychodzić z domu, przejeżdżać się, mężczyźnie tylko prawem obwarował Pan Bóg (cyt. za Grześkowiak, 2012).

Ponadto od opisu Lizbony do opowieści Stelli akcja romansu skupia się głównie na opisywaniu albo cielesności Paskwaliny, albo rozmyślań bohaterki na temat uroków jej ciała. Czerpanie tak wielkiej przyjemności, rozkoszy wręcz, ze słuchania i z przyjmowania wyrazów podziwu od innych oraz fakt, że to zawsze one są punktem wyjścia do analizowania siebie samej, warto rozpatrzeć w kontekście koncepcji mimetycznej René Girarda. Według niej pragnienie ma charakter mimetyczny, a zatem naśladowczy - podmiot naśladuje swój wzorzec i pragnie właśnie tego przedmiotu, który ów wzorzec posiada lub znajduje się w obrębie jego zainteresowania. Struktura mimetyczna pożądania ma kształt trójkąta rozpiętego między podmiotem, przedmiotem i pośrednikiem, przy czym to pośrednik odgrywa kluczową rolę:

Pragnienie seksualne, jak wszystkie pragnienia trójkątne, jest zawsze zaraźliwe. A mówiąc o zarażeniu, mamy na myśli to, że drugie pragnienie kieruje się na ten sam przedmiot, który podsycił pragnienie pierwsze. Naśladować pragnienie swojego kochanka to znaczy pod wpływem jego pragnienia zacząć pożądać siebie (Girard, 2001, s. 112).

Kiedy Paskwalina, ujmując najogólniej, lubi i akceptuje siebie, ponieważ podziwiają ją i pragną jej inni. Nadaje samej sobie wartość, kierując się opiniami mieszkańców Lizbony - pośredników pragnienia. Wszystkie myśli bohaterki sprowadzają się do ciągłego zapewniania siebie o apoteozie płynącej nieprzerwanie z ust mieszkańców miasta. Jej bycie w świecie jest bardzo silnie sankcjonowane przez pragnienie pośredników - „pragnienie jest źródłem osobowości”, pisze Jean-Michel Oughourlian (cyt. za: Zalewski, 2015, s. 17). Pragnienie mimetyczne może być tu więc rozumiane jako element konstytutywny istoty ludzkiej. Zgodnie z mechanizmem pożądania Paskwalina pozuje na obojętną, kierując tym sposobem pragnienie tłumu ku sobie i zyskując status podmiotu autonomicznego, następnie sama zaczyna to pragnienie imitować. Kiedy więc aprobowane i niezmienne (prawdopodobnie od zawsze) status quo zostaje zachwiane przez odmowę Oliwera, osobowość Paskwaliny przechodzi swoisty kryzys tożsamości. Powszechnie spotykane, wydawać by się mogło, niebędące niczym nadzwyczajnym odrzucenie jest przez nią przeżywane jak wydarzenie o wadze co najmniej tragedii, ponieważ ma siłę podwójnego rażenia - po pierwsze, niespodziewanie obraża, jak każde nieodwzajemnienie miłości, po drugie, podaje w wątpliwość skrzętnie konstruowaną przez lata tożsamość. Reakcja bohaterki przywodzi wręcz na myśl rodzaj obłędu:

Który to Paskwalina respons gdy przeczyta, Omdleje bez pamięci i próżno się chwyta Krzesła przeszynionego. Wypadnie jej z ręku Karta nieutrzymana, oczy, pełne wdzięku Niebieskiego dopiero, chmurą się powleką Żałośnie płaczorodą, i wszytkie ucieką Pulsy ożywiające, żeby ratowały 
Tylkoż serca. Ledwie aż ją upamiętały

Służebne białegłowy i odlały różno

Likworami drogiemi.

(Punkt I, w. 907-916)

Prawdziwy kryzys zaczyna się jednak w momencie, kiedy Paskwalina uświadamia sobie, że właśnie staje się obiektem (niepożądanych tym razem) plotek. W trójkącie mimetycznym pośrednikiem jest nie Oliwer, ale cała społeczność kochająca się w heroinie. Społeczność wytwarzająca kolektywną i jednomyślną przemoc w postaci dewaluującej plotki, z powodu której Paskwalina trwa w szaleństwie: „Oczy wywrócone / Twarz i usta jakoby na wieki nie one!” (Punkt I, w. 1013-1014), i z całą stanowczością wypowiada na głos zamiar samobójstwa:

On i teraz Oliwer jest mi przed oczyma

I próżno to - jedno być z sobą nam obiema.

Czego jeśli nie dopnę - owo pas i owo

Wzgórę podwój!

(Punkt I, w. 999-1002)

Jak pisze Girard:

Doświadczenie, które tkwi u podstaw pośrednictwa, każe podmiotowi w swoim życiu i w swoim duchu widzieć największą słabość. I przed tą słabością pragnie uciec w złudną boskość Innego. Podmiot wstydzi się swojego życia i swojego ducha. Zrozpaczony, że nie może być bogiem, szuka świętości we wszystkim, co sprzeciwia się jego duchowi (Girard, 2001, s. 288).

Kiedy Paskwalina analizuje postępującą degradację swojej pozycji społecznej, następuje pierwszy stopnień negacji własnej tożsamości: podawanie w wątpliwość i krytyka dotychczasowych działań. W szaleńczych wykrzyknieniach dochodzi do kontaminacji obojętności Oliwera i poczucia utraty budowanej wcześniej „dobrej sławy”. Niemal cała uwaga Paskwaliny skupia się jednak na wartościującym porównywaniu się z wybranką ukochanego Kornelią - i poddawaniu się ogarniającej bezradności, która wywołuje przede wszystkim chęć natychmiastowej ucieczki, by, jak pisze Czechowicz, „wyleczyć się z miłości i dowiedzieć, kim jest na pewno" (Czechowicz, 2002, s. 223). Owo dowiadywanie się to nic innego, jak tworzenie nowej tożsamości poprzez (jak się okaże: tylko pozorną) negację poprzedniej. „Wyleczyć się z miłości” rozumieć należy jako kategoryczne odcinanie się od seksualnego aspektu życia, czego odpowiednikiem jest oczywiście alegoryczna dychotomia: dom - podróż (por. Sokolski, 1988, s. 91-96; Urbański, 1994, s. 3-13). Podróż, która nie bez przyczyny zmienia się - nawet nie stopniowo, ale bardzo szybko - „w wyprawę po triumf” (Czechowicz, 2002, s. 223) i podczas której wypowiedzi napotkanych postaci oraz odautorskie, wydaje się, wtrącenia stają się kluczem do zrozumienia alternatywnego odczytania parenetycznej rzekomo alegorii.

Przede wszystkim uwadze nie powinno ujść powtórzone drugi raz autodestrukcyjne wręcz wyznanie bohaterki: „Niestetyż mię i rozum, i wszytko opuszcza / A coś umrzeć skrytego 
koniecznie podpuszcza" (Punkt I, w. 1085-1086). Wobec tak skrajnego stanu emocjonalnego Stella zyskuje pozycję niezmiernie wpływowej moralizatorki, wykrzykującej: „a nie mówiłam?!”, i roszczącej sobie prawo do wydawania dyspozycji, które bezpośrednio determinują dalsze losy głównej bohaterki i które, nie wiedzieć czemu, wydają się już dawno przemyślane. Wypowiedź Stelli zamyka się w obrębie 60 wersów i w czasie tak krótkim jest ona w stanie wyłożyć punkt po punkcie właściwe postępowanie, zakładając z góry, że innego wyjścia niż pokuta nie ma. Kobieta zręcznie posługuje się barokową retoryką przedstawień miłości jako złudnego szczęścia, za przykłady podając nieszczęśliwe historie antyczne, żeby finalnie skonstatować: „Bo kto w pierwszym zarazem oparł się jej progu, / Ten już wygrał i może ślub powiesić Bogu” (Punkt I, w. 1137-1138). Zaczyna się tu de facto proces umoralniania Paskwaliny, który koncentruje się głównie na próbie wyrugowania $\mathrm{z}$ jej osobowości wszelkich aspektów związanych z seksualnością. A, jak ironicznie podszeptuje narrator, nie jest to wcale takie łatwe, o ile w ogóle możliwe. Jego apostroficzne zawołanie:

Miłości! To jeszcze jej nie opuszczasz i tu

I do Minerwinego pójdziesz z nią meczytu?

(Punkt I, w. 1191-1192)

- wydaje się niepoważnym, fingowanym zdziwieniem. Pozostając w kontraście z jakże poważną w swych myślach Paskwaliną, zwyczajnie drwi on z przekonania o możliwości gwałtownej przemiany bohaterki. Jednakże, podobnie jak Paweł Bohuszewicz, nie widzę tu postulowanej przez Czechowicz postawy prześmiewczej wobec Paskwaliny - kpina dotyczy raczej potencjalnego czytelnika i przewidywanej interpretacji.

Bohaterka nie jest pewna, jak ma przedstawić się przed Felicyją, ale nie stanowi to jakiejkolwiek przeszkody, ponieważ owa wieszczka zna już jej historię. I wie też, jaką retorykę wobec heroiny stosować, żeby próba wtłoczenia w hardy umysł teologizującej wykładni życia w czystości nie spełzła na niczym - Paskwalinie nie wystarczy powiedzieć, że otrzymała w darze wolną wolę. Po zadumie nad grzeszną naturą ludzką kobieta zostaje natychmiast dowartościowana stwierdzeniem, że jeśli uda jej się przezwyciężyć owe „źwierzęce rządze”, dokona czegoś, „Czemu świat się zdumieje i nie dopiął czego / Nikt z śmiertelnych” (Punkt I, w. 1390-1391). W świetle tak postawionego zadania pokuta Paskwaliny przestaje polegać na umartwianiu się, a staje się trudną drogą ku sławie. I o ile sława była nieodłącznym elementem żywotów wielu świętych i męczennic, ukazywała się jednak dopiero po spełnionym trudzie jako dodatek do nagrody o tyle w Nadobnej Paskwalinie wydaje się przedstawiona przez Felicyję celowo jeszcze przed najtrudniejszym odcinkiem podróży.

Zastanawia już sam fakt, że Paskwalina słucha jej wykładu na temat przyczyn swojej słabości, by chwilę później dowiedzieć się, że wszystko to i tak jest zaplanowanym przez bogów biegiem zdarzeń, którym „zohydziła się” Wenera i dlatego niebianie postanowili właśnie heroiny do swego planu „zażyć” (Punkt I, w. 1415). Paskwalina dostaje sprzeczne informacje - uświadamia jej się doniosłość i ciężar grzesznego zachowania oraz lekceważy się jej znaczenie, odmawia jakiejkolwiek siły sprawczej w tym samym czasie. Kobieta staje się marionetką (sama pew- 
nie wpada w lekką konsternację w związku z rolą, którą przyszło jej odegrać, ale udobruchana zostaje jakże nobilitującym zadaniem), a jej życie spektaklem reżyserowanym przez bogów.

W Punkcie II dostrzec można przede wszystkim, po pierwsze, postępujący proces negacji własnej seksualności, a po drugie, sposób działania mechanizmu, który tenże proces wspomaga. Jakiekolwiek przejawy tęsknoty za utraconym trybem życia i porzucaną tożsamością zostają natychmiast stłumione przez opowieści napotkanych postaci - jak już zresztą zauważył Czesław Hernas, wędrówka protagonistki to w istocie „przegląd ówczesnych mitów o życiu szczęśliwym” (Hernas, 2002, s. 341). Ważniejsza i bardziej zwodnicza jest chyba jednak dla bohaterki możliwość wielokrotnego przedstawiania swojej historii - i z tej możliwości ochoczo korzysta, asekurując się naturalnie afektowaną skromnością. Nie wystarcza przyznanie się do odbywania pokuty. Paskwalina przekształca każdego spotkanego na swojej drodze w adoratora już nie tyle swej urody (choć i takie zachwyty się zdarzają), ile swej działalności. Ponadto rozmowy z rybakiem, pasterzami czy Apollinem różnią się od tych z Dianą - bogini, podobnie jak Felicyja, zwodzi bohaterkę pokrętnymi wyjaśnieniami powodów sytuacji, w której ta się znalazła. Apollo konstatuje: „Owo być spełna przy rozumie / I miłości hołdować - ledwie bóg sam umie” (Punkt II, w. 751-752). W jego ujęciu słabość staje się uzasadniona - nie omija nawet istot boskich, dlaczego miałaby więc zostać przezwyciężona przez Paskwalinę? Pewniejsza siebie bohaterka wędruje do Diany, by ta krótko ucięła jej usprawiedliwianie się słowami: „Raczej złe twoje szafowanie / Talentami danemi i rozumem z nieba / Jest ci tego przyczyną" (Punkt II, w. 938-940).

Samo spotkanie z Dianą, chętnie analizowane już we wcześniejszych badaniach (por. Czechowicz, 2002; Bohuszewicz, 2008), wydaje się jednym z bardziej znaczących w utworze. Nadzwyczaj silne jest tu chrystianizowanie pojęć mitologicznych - w wersach od 980 do 1000 pojawiają się wręcz sam Bóg explicite, wyobrażenie Sądu Ostatecznego, potem z kolei Olimp o cechach chrześcijańskiego nieba. Jak zauważa Hernas, sama Diana może, ale nie musi występować jako „literacki synonim Matki Boskiej” (Hernas, 2002, s. 340), badacz wspomina też o trudnościach w kwalifikacji postaci bogów w Nadobnej Paskwalinie, niezrozumiałej symbolice kultowej. O rozchwianym statusie ontologicznym bogów pisze także Czechowicz. Istotna jest przede wszystkim ich ogromna siła perswazji, która pozwala na „zagadanie” jakichkolwiek zdroworozsądkowych reakcji heroiny na absurdalne fragmenty opowieści moralizatorskich². Kiedy konieczne jest wsparcie i zmuszenie Paskwaliny do dalszej podróży, Apollo przydaje jej „komfortowy status ofiary” (Czechowicz, 2002, s. 226). Chwilę później, zaślepiona własną pychą, zostaje przez Dianę wytrącona z równowagi - bogini jej ów status odbiera, przyczynę upadku upatrując głównie po stronie bohaterki. Heroina wychodzi więc od niej z przekonaniem, że czystość powinna być stawiana ponad uczciwością. Pojęcie braku moralności zostaje utożsamione z rozwiązłością seksualną, chęć prokreacji jawi się jako jedyna dopuszczalna przy-

2 Paskwalina zauważa sprzeczności w mowie Diany:

Pominię słowa twoje,

Panno święta, dopiero, że w jarzmo to swoje

Poniewolnie nikogo Wenus nie pociąga,

Oprócz, kto się naraża i sam w nie zaprząga

(Punkt II, w. 1099-1102). 
czyna stosunku, a sama Paskwalina utwierdzona kolejny raz w swej boskości wyrusza w dalszą podróż, by udowodnić wszystkim zezwierzęconym przedstawicielom jej gatunku, że należy żyć inaczej - wyrzec się miłości.

W tym momencie dopełnia się schemat mimetyczny - widać wyraźnie, jak seksualność Paskwaliny dochodzi do głosu jeszcze w Lizbonie, przełamuje społeczną normatywność i w rezultacie bohaterka staje się tzw. kozłem ofiarnym. Wydaje się z początku, że przyczyną kryzysu tożsamości Paskwaliny są plotkujący mieszkańcy miasta. Jednak po przeanalizowaniu wydarzeń i rozmów zawartych w Punkcie II oczywiste staje się, że rolę faktycznego oprawcy (choć to może za mocne słowo) odgrywają piewcy społecznie przyjętych konwenansów. Słynnego Girardowskiego „mordu na koźle ofiarnym”, czyli na własnej seksualności, dokonuje sama Paskwalina, której nie wystarcza już odebrana przez Dianę rola ofiary. Przezwyciężając stopniowo swoje „zwierzęce żądze”, uruchamia w sobie sadyzm erotyczny. „Podmiot pragnący, znużony rolą męczennika, postanawia stać się katem" (Girard, 2001, s. 191) i już nie tłumienie, ale ostateczne unicestwienie swojej seksualności staje się celem bohaterki.

Jest to specyficzny, bo transgresyjny, a nie unicestwiający mord, który w dodatku podlega „stopniowej rytualizacji dla celów prewencyjnych” (Urbańska, 1997, s. 36) - spowiedzi. Powtarzana $\mathrm{z}$ uporem przed każdą napotkaną postacią historia przewinień to, obok zwykłego moralizowania, wzór dobrego postępowania zapobiegawczego, rodzaj długotrwałej ascezy. Kolejny raz sprawdza się tutaj myśl Girarda: „Każde odstępstwo od zasady obłudy musi zostać odkupione jeszcze większym utajeniem pragnienia” (Girard, 2001, s. 162). Nawet na samym końcu, po trudach wędrówki ksieni Beliza zmusza Paskwalinę do spowiedzi, wygłaszając uprzednio dość obszerną przemowę podkreślającą znaczenie tegoż aktu. Dekonstrukcji tych zabiegów Twardowskiego dokonuje Paweł Bohuszewicz (Bohuszewicz, 2008, s. 153), postrzegając spowiedź z grzechu nieczystości jako „dyskursywizację seksu” (Foucault, 2000, s. 20) opisaną przez Michela Foucaulta. Tak jak przywoływany przez Bohuszewicza Hamlet „znika w mgławicy słów” i szerzej już pojęty podmiot „zamiast odkrywać i kontrolować jego prawdę, produkuje ją i staje się jej zakładnikiem” (Bohuszewicz, 2008, s. 153), Paskwalina dokonuje zamachu na niemal fundamentalnym czynniku kształtującym jej podmiotowość, gubi się, jest zwodzona i przyjmuje nowy dla siebie wzór kobiety - pokutnicy oraz fundatorki klasztoru.

Ale z jaką stanowczością ona ten wzór tworzy - rozpoczynając jakże heroicznym aktem połamania łuku Kupidyna, poprzedzonym projekcjami przyszłej sławy, poprzez umartwianie się przed Satyrem i egzaltowaną skruchę, a potem - wobec Belizy - zachwyt nad przyszłością, na ponownym „monstrowaniu się” w oknie (oczywiście już w innych celach) kończąc. Tutaj faktycznie słychać ów chichot Twardowskiego opisywany przez Czechowicz, więcej widać rozkosz, jaką Paskwalina znajduje w życiu pokutnym. Czesław Hernas pisze, że „szczęście Paskwaliny to duma ze zwycięstwa nad Wenerą, duma z własnej piękności [...], to wolność, zdrowie, wczasy, sen spokojny, życie w wegetariańskim przepychu” (Hernas, 2002, s. 342). Ale to także specyficzne poczucie niezależności. Jak już zostało udowodnione, Paskwalina w swym „nieczystym” życiu nie narzekała na brak autonomiczności podmiotowej (a raczej - tak jej się przez większość czasu wydawało). Podczas podróży jednakże zaczyna tracić nie tylko znaną sobie tożsamość, ale również prawo do samostanowienia - ograniczana przez przewodników-moralizatorów korzysta wprawdzie chętnie z ich pomocy, ale jakiekolwiek próby wejścia 
z nimi w polemikę (przykładowo analizowana już rozmowa z Dianą) są tłamszone. Transgresja przywraca jej i niezależność, i narcystyczną tożsamość osobowościową (przed nikim nie musi się spowiadać, ponieważ osiągnęła ideał kobiecości - czystej, wolnej od pożądania - i jest ponownie przez wszystkich podziwiana).

Simone de Beauvoir zwraca w Drugiej płci uwagę na fakt, że „żarliwość mistyczna, podobnie jak miłość i narcyzm, może stać się częścią czynnego i niezależnego życia” (Beauvoir, 2014, s. 730). O tym samym wspomina zresztą Maria Bogucka, odnosząc się konkretnie do sytuacji kobiet w XVI i XVII wieku - już w samym zwrocie do Boga zawierało się poczucie wolności, ponieważ było to coś niezależnego od mężów czy ojców; ponadto wyjście do kościoła umożliwiało opuszczenie domu i udział w życiu publicznym. Nie bez znaczenia wydaje się też w Nadobnej Paskwalinie figura klasztoru, który zaczął być postrzegany w badaniach jako „alternatywa życiowa dla wielu kobiet pragnących uniknąć małżeństwa, miejsce samorealizacji (dostęp do wykształcenia, możliwości uprawiania zajęć intelektualnych) niemożliwej w tej epoce w obrębie rodziny" (Bogucka, 1998, s. 95).

Nie zamierzam tutaj umiejscawiać Samuela Twardowskiego w obrębie protofeministów, jednakowoż nie należy odmawiać mu, kolejny już raz, świetnego zmysłu obserwacji, tym razem sytuacji kobiety w społeczeństwie. Wychodząc od spraw związanych z seksualnością Paskwaliny, włącza się on niejako w tzw. spór o kobiety czy kwestię kobiecą, querelle des femmes (por. Bogucka, 2005, s. 181), i - wydaje się - daleki jest od definiowania kobiety wzorem Richarda Steele’a, który w wieku XVIII stwierdza, że „kobieta to córka, siostra, żona i matka - skromny dodatek do rodu męskiego" (cyt. za: Dziechcińska, 2001, s. 12). Paskwalina nie jest żadną z nich, nie jest nawet kochanką. Pojedyncze oskarżenia wystosowywane w stronę „płci śliskiej” czy „słabej” w utworze są raczej kolejną próbą obnażenia zaobserwowanych skłonności społeczeństwa do stereotypizacji i szukania winnego.

Jak zauważyła Czechowicz, Twardowski to autor „wyrafinowany i spodziewa się odbiorcy, który nie da się zwieść pozornej - i łatwej - oczywistości dyskursu eksplicytnego" (Czechowicz, 2002, s. 230). Ujawnia się on z całą pewnością na początku i końcu dzieła, prezentując swą ambiwalentną postawę wobec domniemanej reformy świata i powrotu wieków niewinności, tym samym demonstrując też swój stosunek do transgresji heroiny, a więc zagadnienia seksualności w ogóle. Nie odmawiałabym mu prawa do zajęcia stanowiska krytycznego wobec ówczesnych przedstawień erotyzmu, zwłaszcza w kontekście licznych ironicznie nacechowanych obserwacji innych powszechnych wtedy zjawisk - z drwiną nawołuje przecież do podokiennych śpiewaków, wyśmiewając ich paraklausithyrony, z właściwą epoce baroku malarskością opisuje ciało Paskwaliny, przełamując tym momentami ponurą, ascetyczną narrację, a w końcu intencjonalnie „aranżuje [...] dwuznaczne sytuacje” (Czechowicz, 2002, s. 230).

Ciekawe byłoby prześledzenie tekstu Nadobnej Paskwaliny w kontekście innych utworów podejmujących kwestię kobiecą, jak Jeftes czy Żywot Marii Magdaleny grzesznice i nawróconej tam także z powodu podstawowych dla obydwu dzieł sensualizmu, „afektowanej drobiazgowości” (Wojsław, 2008, s. 245) i petrarkistycznej symboliki.

3 Możliwość porównawcza sygnalizowana już przez Katarzynę Wojsław (Wojsław, 2008, s. 250). 
Gęstość tekstu i nagromadzenie postaci utrudniają interpretację Nadobnej Paskwaliny, nie ulega jednak wątpliwości, że - jeśli potraktujemy kreację protagonistki poematu jako studium kobiecej seksualności - otworzą się kolejne ścieżki interpretacyjne i nowe możliwości rozumienia poszczególnych bohaterów. Ironiczny opis śmierci Kupidyna, choć wieńczący dzieło, może okazać się nie aż tak istotny w obliczu skomplikowanych relacji i ukrytych komentarzy, jak najbardziej wartych ponownej analizy.

\section{Bibliografia podmiotowa}

Twardowski, S. (1980). Nadobna Paskwalina z hiszpańskiego świeżo w polski przemieniona ubiór. Wstęp i oprac. J. Okoń. Wrocław: Zakład Narodowy im. Ossolińskich.

\section{Bibliografia przedmiotowa}

Beauvoir, S. de. (2014). Druga płeć. Tłum. G. Mycielska, M. Leśniewska. Warszawa: Czarna Owca.

Bogucka, M. (1998). Białogłowa $w$ dawnej Polsce. Warszawa: Wydawnictwo Trio.

Bogucka, M. (2005). Gorsza płeć. Kobieta w dziejach Europy od antyku po wiek XXI. Warszawa: Wydawnictwo Trio.

Bohuszewicz, P. (2008). Dwoista natura miłości. O „Nadobnej Paskwalinie” Samuela Twardowskiego. W: R. Krzywy (red.), Erotyzm w literaturze staropolskiej (s. 143-155). Warszawa: Wydawnictwa Uniwersytetu Warszawskiego.

Brückner, A. (1927). Paskwalina S. Twardowskiego. Pamiętnik Literacki, 24 (1), 14-23.

Czechowicz, A. (2002). Sprzeczne komunikaty. Alegoria i mowa podwójna w „Nadobnej Paskwalinie”. W: K. Meller, J. Kowalski (red.), Wielkopolski Maro. Samuel ze Skrzypny Twardowski i jego dzieło w wielkiej i małej Ojczyźnie (s. 221-234). Poznań: Wydawnictwo Poznańskie Studia Polonistyczne.

Dziechcińska, H. (2001). Kobieta w życiu i literaturze XVI i XVII wieku. Zagadnienia wybrane. Warszawa: Wydawnictwo Instytutu Badań Literackich PAN.

Foucault, M. (2000). Historia seksualności. Przeł. B. Banasiak, T. Komendant, K. Matuszewski. Warszawa: Wydawnictwo Czytelnik.

Girard, R. (2001). Prawda powieściowa i kłamstwo romantyczne. Przeł. K. Kot. Warszawa: Wydawnictwo KR. Grześkowiak, R. (2012). Złota klatka. Pozycja kobiety w czasach nowożytnych. Pobrane z: https://www.wilanow-palac.pl/zlota_klatka_pozycja_kobiety_w_czasach_nowozytnych.html (20.01.2020).

Hernas, C. (2002). Barok. Warszawa: Państwowy Instytut Wydawniczy.

Kuchowicz, Z. (1992). Człowiek polskiego baroku. Łódź: Wydawnictwo Łódzkie.

Künstler-Langer, D. (2002). Mądrość i miłość w romansie „Nadobna Paskwalina” Samuela Twardowskiego. W: K. Meller, J. Kowalski (red.), Wielkopolski Maro. Samuel ze Skrzypny Twardowski i jego dzieło w wielkiej i małej Ojczyźnie (s. 211-220). Poznań: Wydawnictwo Poznańskie Studia Polonistyczne.

Kuran, M. (2008). O erotyzmie w twórczości Samuela Twardowskiego. W: R. Krzywy (red.), Erotyzm w literaturze staropolskiej (s. 156-189). Warszawa: Wydawnictwa Uniwersytetu Warszawskiego. 
Lichański, J.Z. (1999). „Stara kobieta z węgielnicą” Piotra Pawła Rubensa, czyli szkice do portretu kobiety w literaturze staropolskiej [w twórczości pisarzy: Jan Kochanowski, Szymon Szymonowic, Aleksander Magnuszewski]. W: I. Iwasiów, P. Urbański (red.), Pogranicza wrażliwości w literaturze dawnej oraz wspótczesnej (s. 135-159). Cz. 1: Miłość. Szczecin: Wydawnictwo Naukowe Uniwersytetu Szczecińskiego.

Obremski, K. (2016). Samuela Twardowskiego Dafnis: małżeństwo - retoryka - prefeminizm Sceny XIII. Śląskie Studia Polonistyczne, 8 (1-2), 287-300.

Okoń, J. (1980). Wstęp. W: S. Twardowski. Nadobna Paskwalina z hiszpańskiego świeżo w polski przemieniona ubiór (s. III-XCI). Wstęp i oprac. J. Okoń. Wrocław: Zakład Narodowy im. Ossolińskich.

Pliszka, M. (2002). „Nadobna Paskwalina” Samuela Twardowskiego jako przykład poezji wizyjnej. W: K. Meller, J. Kowalski (red.), Wielkopolski Maro. Samuel ze Skrzypny Twardowski i jego dzieło w wielkiej i małej Ojczyźnie (s. 244-262). Poznań: Wydawnictwo Poznańskie Studia Polonistyczne.

Raubo, G. (2002). Oko i rozum. Myśl antropologiczna w „Nadobnej Paskwalinie” Samuela Twardowskiego. W: K. Meller, J. Kowalski (red.), Wielkopolski Maro. Samuel ze Skrzypny Twardowski i jego dzieło w wielkiej i małej Ojczyźnie (s. 189-210). Poznań: Wydawnictwo Poznańskie Studia Polonistyczne.

Sokolski, J. (1988). „Miejsce to zowia żywot...”. Staropolskie romanse alegoryczne. Wrocław: Wydawnictwo Uniwersytetu Wrocławskiego.

Urbańska, A. (1997). Koncepcja mimesis René Girarda. Etnografia Polska, 41 (1-2), 21-45.

Urbański, P. (1994). Glosy do „Nadobnej Paskwaliny”. Pamiętnik Literacki, 85 (1), 3-13.

Wiśniewska, H. (2003). Świat płci żeńskiej baroku zaklęty w słowach. Lublin: Wydawnictwo Uniwersytetu Marii Curie-Skłodowskiej.

Wojsław, K. (2008). Maria Magdalena grzesznica i nawrócona. Siedemnastowieczna polska proza marinistyczna. Terminus, 10 (1), 241-253.

Zalewski, C. (2015). Źródło. René Girard i literatura. Kraków: Wydawnictwo Uniwersytetu Jagiellońskiego. 


\section{Sexuality of Paskwalina or about the properties of the poem by Samuel Twardowski once again}

\section{Summary}

The main purpose of the text is to analyze the problem of sexuality presented in the poem by Samuel Twardowskiof entitled "Nadobna Paskwalina” (“The beautiful Paskwalina”). The analysis was based on previous research: the mimetic concept of René Girard and an attempt at feminist reading of romance. The author shows the process of constructing a woman's personality on the foundations of admiration on the part of the male sex and confronts it with the traditional model of a woman which dominated in the old ages. The next part of the text presents the relationship between the process of building and collapse of the Paskwalina's identity according to the concept of René Girard. The heroine's journey and the significance of the influence of her guides are being analyzed. The poem is interpreted as an extensive commentary by Samuel Twardowski on the observed realities of everyday life of the Catholics, and the finale of this romance as a girardian murder of the heroine's sexuality, which acquires a transgressive character.

Słowa kluczowe: seksualność kobieca, kobieta w literaturze staropolskiej, konstrukcja tożsamości, querelle des femmes, alegoria, koncepcja mimesis, René Girard, feminizm

Keywords: female sexuality, woman in Old Polish literature, identity construction, "querelle des femmes", allegory, mimesis concept, René Girard, feminism 
http://rcin.org.pl 